\title{
COMMUNITY DEVELOPMENT UMKM EKS LOKALISASI DOLLY MELALUI DIGITAL PLATFORM DALAM MENGHADAPI COVID-19
}

\section{COMMUNITY DEVELOPMENT OF UMKM EX LOCALIZATION OF DOLLY THROUGH DIGITAL PLATFORM IN FACING COVID-19}

\author{
Putu Aditya Ferdian Ariawantara', Djoko Adi Prasetyo², Philipus \\ Keban $^{3}$ \\ ${ }^{1,3}$ Prodi Ilmu Administrasi Negara, FISIP Universitas Airlangga \\ ${ }^{2}$ Prodi Antropologi, FISIP Universitas Airlangga \\ e-mail: putu.aditya.ferdian.ariawantara@ fisip.unair.ac.id
}

\begin{abstract}
The closure of Dolly's localization in 2014 had a significant impact on the economy of the surrounding community. Where Dolly is known as the largest prostitution place in Southeast Asia, which is in Putat Jaya, Sawahan District, City of Surabaya. The solution that has been carried out by the Surabaya City Government is to provide training for MSMEs (Micro, Small and Medium Enterprises), in order to create economic growth and opportunities for new creative businesses in local society. To strengthen the MSMEs sector that has been initiated by the Surabaya City Government, our team wants to provide an added value to these MSMEs by carrying out capacity building and a touch of digital platforms to develop the community business sector. So, existing MSME products can be promoted according to the correct and appropriate techniques. This aims to create a creative economy that can be independent from localization activities and can survive the Covid-19 pandemic.
\end{abstract}

Key words: capacity building, community development, community dedication, digital marketing

\section{abstrak}

Penutupan lokalisasi Dolly pada tahun 2014 memiliki dampak yang signifikan terhadap perekonomian masyarakat di sekitarnya. Dolly terkenal sebagai tempat prostitusi terbesar di Asia Tenggara yang berada di Kelurahan Putat Jaya, Kecamatan Sawahan, Kota Surabaya. Solusi yang pernah dilakukan oleh Pemerintah Kota Surabaya adalah dengan memberikan pelatihan untuk UMKM (Usaha Mikro, Kecil, dan Menengah), agar dapat menciptakan pertumbuhan ekonomi dan peluang bagi usaha-usaha kreatif baru di masyarakat. Untuk memperkuat sektor UMKM yang sudah digagas oleh Pemerintah Kota Surabaya tersebut, maka tim kami ingin memberikan suatu nilai tambah pada UMKM tersebut dengan dilakukannya pembangunan kapasitas dan sentuhan platform digital untuk mengembangkan sektor usaha masyarakat. Sehingga, produk UMKM yang ada bisa dipromosikan sesuai dengan teknik yang benar dan tepat. Hal ini bertujuan untuk mewujudkan ekonomi kreatif yang bisa mandiri tidak tergantung pada aktivitas lokalisasi dan bisa bertahan di masa pandemik Covid-19.

Kata kunci: pembangunan kapasitas, pengembangan komunitas, pemasaran digital, pengabdian masyarakat 


\section{Pendahuluan}

Penutupan lokalisasi Dolly pada tahun 2014 memiliki dampak yang signifikan terhadap perekonomian masyarakat di sekitarnya. Dolly terkenal sebagai tempat prostitusi terbesar di Asia Tenggara yang berada di Kelurahan Putat Jaya, Kecamatan Sawahan, Kota Surabaya. Pada awalnya, warga Gang Dolly secara tidak langsung dapat membuka lapangan pekerjaan sepeti buruh cuci, masak, dan lain sebagainya. Akhirnya, terpaksa harus menutup usaha tersebut sehingga angka pengangguran pun meningkat. Hal ini mengakibatkan jumlah angka anak putus sekolah juga bertambah sebab orang tua tidak mampu memberikan dana pendidikan. Sehingga, anak lebih rentan untuk bisa terjerumus terhadap pergaulan bebas karena pengaruh lingkungan yang kuat. Solusi yang pernah dilakukan oleh Pemerintah Kota Surabaya dengan memberikan pelatihan untuk UMKM (Usaha Mikro, Kecil, dan Menengah) seperti goody bag, sablon, minyak rambut (pomade dan semir), kerajinan tangan, lukisan. Ada 13 UMKM dibidang kuliner yaitu olahan bandeng, Jarwo Tempe, Kerupuk Sami Jali, Pangsit Hijau, rujak, UMKM Puja (telur asin, botok telur asin), UMKM Squel (olahan keripik), UMKM Vigts (jamu herbal), Gendis (bumbu pecel), UMKM Henrik (olahan semanggi dan es puter), dan olahan minuman dari rumput laut, empat kelompok UMKM batik (Jarak Arum, Alpujabar, Canting Surya, dan Warna Ayu). Selain itu, juga ada fasilitas pengembangan usaha berupa gedung serbaguna dan ruang pamer produk khas warga Dolly. Namun, hal ini dinilai kurang tepat sasaran sehingga belum bisa mengatasi akar permasalahan. Sebab kemampuan masyarakat eks lokalisasi Dolly tidak bisa disamaratakan, dimana setiap orang memiliki kapasitas yang berbeda-beda. Maka, permasalahan mendasar yang harus diselesaikan adalah peningkatan

perekonomian yang bisa menurunkan angka putus sekolah. Berdasarkan hasil survei yang telah dilakukan oleh tim kami, masyarakat Gang Dolly memiliki kemampuan marketing untuk dikembangkan melalui capacity building yang sesuai dengan permasalahan. Sehingga, produk UMKM yang ada bisa dipromosikan sesuai dengan teknik yang benar dan tepat. Oleh karena itu, tim mengusulkan gagasan pelatihan digital marketing terhadap masyarakat eks lokalisasi Dolly melalui community development. Hal ini bertujuan untuk mewujudkan ekonomi kreatif di Gang Dolly yang bisa mandiri tidak tergantung pada aktivitas lokalisasi. Dimana community development merupakan pelibatan masyarakat secara langsung yang dimulai dari perencanaan, pelaksanaan bahkan setelah program selesai dengan tiga karakter utama, yaitu berbasis masyarakat (community based), berbasis sumber daya setempat (local resource based) dan berkelanjutan (sustainable) (Triyono, 2014). Tantangan yang dihadapi pada tahun 2020 ini adalah penyebaran Corona Virus Disease (COVID-19) dimana seluruh kegiatan diorientasikan menggunakan platform digital, untuk menghindari bertemunya orang secara langsung dan mencegah penyebaran virus tersebut. Hal ini menjadi tantangan baru dimana tidak semua masyarakat bisa membuat dan mengoperasionalkan platform digital untuk mendukung kegiatannya. Khususnya UMKM di Gang Dolly yang sebagian besar masih terkendala dibidang pemasaran akan mengalami kesulitan. Oleh karena itu kami sebagai tim pengabdian masyarakat, akan membuat sebuah platform digital untuk memudahkan pemasaran dan product knowledge dari UMKM Gang Dolly agar diketahui dan dapat diakses semua masyarakat khususnya di Indonesia melalui perangkat digital baik smartphone maupun komputer. Penutupan lokalisasi Dolly yang dilakukan oleh Pemerintah Kota Surabaya, secara langsung berdampak pada profesi keseharian masyarakat Gang Dolly. 
Masyarakat yang dulunya bekerja dalam lingkungan lokalisasi harus mencari pekerjaan lain. Dilain sisi, pemerintah Kota Surabaya sendiri sudah menyiapkan lapangan pekerjaan bagi masyarakat di kawasan Dolly. Namun seiring perkembangan waktu, usaha yang dilakukan masyarakat dalam memajukan UMKM pun mengalami kegagalan. Kegagalan dalam hal pengembangan UMKM terjadi karena kurangnya pasar dalam menerima produk yang ditawarkan. Padahal Pemerintah Kota Surabaya sudah membantu menyediakan Sarana dan Prasarana, seperti sentra UMKM yang dibangun di Kelurahan Putat Jaya.

Produk-produk UMKM juga beragam, beberapa diantaranya adalah batik, Keripik Samijali, dan minuman rumput laut dengan merek Orumy. Tantangan yang dihadapi justru adalah bagaimana masyarakat bisa mengenal produk tersebut dan tertarik untuk mencoba membelinya. Hal ini harus didorong oleh sentuhan Iptek, sehingga untuk produk tersebut bisa dikenal oleh masyarakat, ditambah lagi dengan adanya pandemik Covid-19 digital marketing adalah salah satu solusi yang efektif agar sebuah produk bisa menjadi "viral".

Mitra yang akan kami jadikan obyek pada pengmas kali ini adalah UMKM di Gang Dolly khususnya yang terletak pada RT 5 dan RT 6, RW 12, Kelurahan Putat Jaya. Pola manajemen yang digunakan pada UMKM disini masih menggunakan semi tradisional, dimana masih terdapat pola-pola manajemen kekeluargaan untuk mengelola UMKM tersebut. Empat aspek dalam manajerial UMKM yang kami temukan antara lain sebagai berikut: a). Keuangan, di mana pengelolaan keuangan usaha mereka masih sangat sederhana bahkan masih belum mampu memisahkan antara keuangan usaha dengan keuangan pribadi. Kondisi ini diperparah dengan tidak adanya pencatatan transaksi keuangan sehingga perputaran modal usaha menjadi tidak jelas dan tidak terkontrol. Pola yang demikian menyebabkan usaha mereka menjadi tidak berkembang bahkan tutup karena kehabisan modal.; b). Produksi/operasional, dalam perkembangannya mereka mengalami berbagai kendala teknis dan teknologi, selain itu juga UMKM minim untuk berinovasi dan mengembangkan suatu produknya; c). Pemasaran, lingkup pemasaran usaha ibu-ibu dampingan ini masih sangat terbatas di lingkungannya sendiri baik sebatas RT, RW, maupun desa saja sehingga sulit untuk berkembang dengan maksimal. Permasalahan lain yang dihadapi adalah kemampuan daya beli masyarakat yang sangat rendah sehingga harga jual produk mereka juga rendah. Perilaku konsumen yang lebih menyukai pembelian secara kredit juga menjadi salah satu faktor penghambat karena perputaran dananya menjadi lambat bahkan cenderung macet; dan d). Sumber daya manusia, aspek sumber daya manusia ibu-ibu dampingan ini masih tergolong berpendidikan dan berpengalaman rendah sehingga kemampuan dan wawasan mereka juga masih sangat rendah.

Ekonomi kreatif di era industrialisasi 4.0 dan mulainya era society 5.0 saat ini memiliki jangkauan yang sangat besar. Adanya pemanfaatan teknologi juga akan menjadi faktor pendukung terbesar dalam mencapai ekonomi yang maju. Dolly sendiri memiliki potensi lokal yang yang berpeluang besar jika dapat dimanfaatkan dengan baik. Namun melihat kondisi masyarakat Dolly yang belum dapat memanfaatkan teknologi dengan baik dalam mewujudkan ekonomi yang kreatif, maka dibutuhkan langkah-langkah dalam menghadapi permasalahan tersebut. Langkah-langkah umumnya tersebut sebagai berikut: a). Analisis Kondisi Masyarakat Kelurahan Putat Jaya khususnya eks lokalisasi Dolly; b). Perencanaan dan Perumusan platform yang digunakan, dalam hal ini platform yang menyediakan jasa penjualan sangatlah banyak. Oleh karena itu perlu ada pengenalan platform serta edukasi kepada 
masyarakat mengenai kekuatan dan kelemahan dari masing-masing platform; c). Sosialisasi dan Edukasi dibutuhkan untuk dapat memberikan gambaran dan bentuk praktik secara langsung kepada masyarakat melalui pelatihan pengembangan kemampuan dalam memanfaatkan teknologi dalam hal ini menjadi reseller produk lokal guna meningkatkan perekonomian; d). Uji Coba Implementasi, dengan langsung menerapkan kepada masyarakat luas dengan capaian mendapatkan keuntungan; dan e). Evaluasi dan Monitoring, dilakukan guna mengontrol pelaksanaan yang dilakukan stabil.

\section{METODE PELAKSANAAN MASYARAKAT}

Sebelum kami menentukan metode untuk pelaksanaan program pengabdian kepada masyarakat, maka berdasarkan hasil survei yang sudah kami lakukan terdapat permasalahan yang dihadapi oleh mitra dan solusinya adalah sebagai berikut:

Permasalahan UMKM pada RT 5 dan RT 6, RW 12, Kelurahan Putat Jaya seperti yang sudah kami kemukakan pada paragraf sebelumnya diatas, akan tetapi setelah berdiskusi dengan mitra kami lebih fokus kepada permasalahan sebagai berikut: a). Pemasaran produk yang dilakukan masih semi tradisional, walaupun beberapa sudah memasarkan melalui media digital dan sosial media, akan tetapi belum efektif. ; b). Product knowledge oleh masyarakat Surabaya sendiri yang belum mengetahui secara detail mengenai produk apa saja yang terdapat pada UMKM pada RT 5 dan RT 6, RW 12, Kelurahan Putat Jaya. Sehingga dibutuhkan reviewer dan influencer pada sosial media untuk bisa mengangkat produk UMKM pada RT 5 dan RT 6, RW 12, Kelurahan Putat Jaya; dan c). Manajerial UMKM yang masih belum profesional, sehingga antara cash flow tidak seimbang.

Dengan adanya permasalahan yang sudah dikemukakan tersebut, maka tim berencana untuk memecahkan persoalan tersebut sesuai dengan tiga fokus yang ada, antara lain sebagai berikut: a). Permasalahan pemasaran produk. Untuk mengatasi permasalahan permasalahan produk yang sementara ini UMKM pada mitra juga sudah menggunakan sosial media namun belum berdampak secara signifikan, kami menawarkan untuk membuat suatu platform digital sebagai solusi untuk meningkatkan pemasaran produk dan memaksimalkan konten dari jejaring dunia digital secara luas; b). Meningkatkan product knowledge masyarakat secara luas. Permasalahan kedua adalah mengenai sosialisasi produk yang dimiliki oleh UMKM pada mitra yang belum masif. Kami sebagai tim memiliki solusi yaitu membuatkan konten mengenai produk- produk yang dihasilkan oleh UMKM pada mitra dengan media Youtube dan perangkat sosial media lainnya. Harapannya adalah agar produk hasil UMKM pada mitra menjadi suatu produk yang memiliki nilai "viral" sehingga menyedot keingintahuan masyarakat secara luas, dan keinginan masyarakat untuk memiliki produk tersebut. Ke depan kami juga akan menggunakan jasa influencer atau endorsement untuk produk-produk UMKM terpilih, sehingga bisa meningkatkan pemasaran produk tersebut; c). Manajerial UMKM. Permasalahan ketiga adalah mengenai manajerial UMKM pada mitra yang masih belum sepenuhnya profesional, untuk itu kami memiliki solusi adalah dengan mengadakan pelatihan manajerial UMKM, sehingga dengan adanya pelatihan ini UMKM pada mitra bisa menerapkan dan mengaplikasikan tips dan trik bagaimana mengelola keuangan, mengelola SDM, dan produksi agar lebih optimal. 


\section{Alur Kegiatan Pengabdian Masyarakat UMKM Gang Dolly}

Untuk menjalankan program pengabdian masyarakat terhadap UMKM pada mitra tersebut, maka kami akan mengemukakan metode pelaksanaan yang secara spesifik (alur kegiatan dapat dilihat pada gambar 1) sebagai berikut ini, pertama melakukan analisis kondisi masyarakat; dimana kami melakukan pemetaan mengenai kondisi masyarakat sekitar, khususnya kondisi UMKM. Dari kegiatan pemetaan ini didapatkan data eksisting mengenai UMKM di Gang Dolly terutama yang masih aktif dalam era pandemik Covid-19. Kedua, merencanakan dan merumuskan platform; pada tahapan kedua ini kami melakukan perancangan platform digital dan menyiapkan kelengkapan mengenai e-commerce yang dapat dengan mudah digunakan oleh masyarakat. Sehingga harapannya selain produk UMKM tersebut ditampilkan dalam platform yang kami buat, juga bisa dimasukkan dalam konten $e$ commerce lain sehingga menambah jangkauan pasar. Ketiga, melakukan sosialisasi dan edukasi; tahapan ketiga ini merupakan tantangan tersendiri bagi kami, dimana di era pandemik Covid-19 ini kegiatan berkumpul dalam satu ruangan memang sangat dibatasi sehingga peserta tidak dapat kami undang seluruhnya untuk mengikuti pelatihan. Sehingga kegiatan yang kami lakukan adalah menjaga protokol kesehatan dengan ketat. Keempat, uji coba dan implementasi; setelah melakukan sosialisasi dan edukasi kami akan mencoba untuk melakukan pembiasaan dimasyarakat dalam mencoba platform digital yang kami rancang dan e-commerce lain yang kami gunakan dalam mempublikasikan produk UMKM tersebut. Sehingga aktivitas jual beli sudah dapat mereka lakukan.

Kelima, monitoring dan evaluasi; tahapan kelima ini kami akan melakukan monitoring dan evaluasi mengenai aktivitas UMKM yang sudah mencoba menggunakan platform kami, atau e-commerce yang ada. Kami akan melihat seberapa besar jumlah produk UMKM yang berhasil mereka jual dan yang paling penting adalah menciptakan kemandirian mereka dalam menggunakan aplikasi e-commerce tersebut. Keenam, kaderisasi; pada tahapan terakhir kami akan melakukan kaderisasi, yaitu para peserta kegiatan pengabdian kepada masyarakat yang memang kami anggap mampu untuk menjalankan platform kami dan market place yang sudah tersedia. Selain itu, kader disini adalah orang-orang yang memikul tanggungjawab untuk aktivitas yang ada di UMKM.

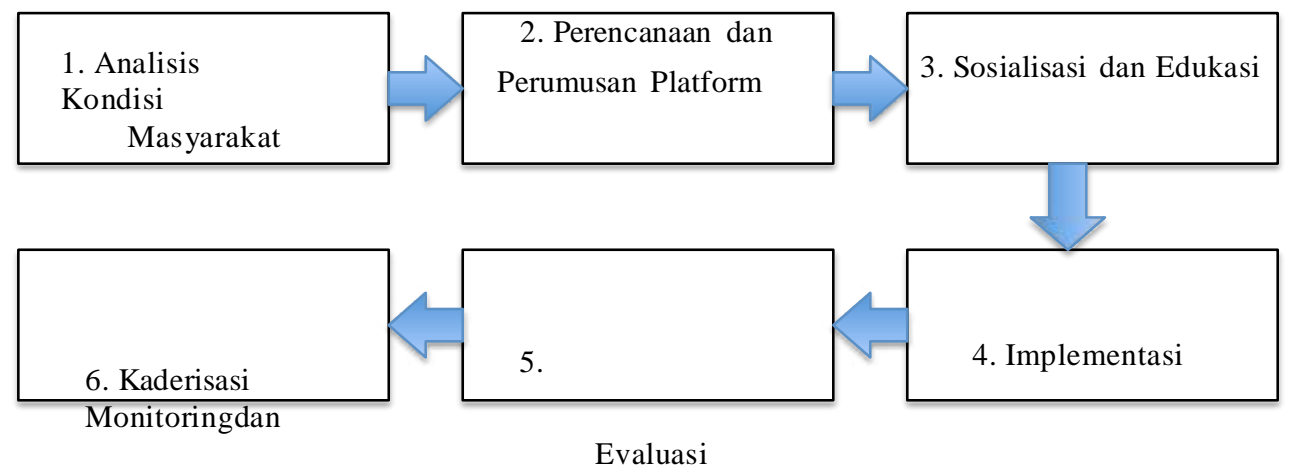

\section{Gambar 1. Alur Kegiatan Pengabdian Kepada Masyarakat UMKM Gang Dolly}




\section{Hasil dan Pembahasan}

Wabah virus Corona menyebabkan keadaan darurat kesehatan global, dan perlambatan ekonomi global. Perdagangan, investasi, dan lapangan kerja semuanya telah terpengaruh dan krisis akan berdampak pada pencapaian Tujuan Pembangunan Berkelanjutan. Perkembangan wabah virus corona menjangkiti berbagai sektor dengan skala kerugian yang cenderung sangat luas dan multisektor. Sektor yang paling terpengaruh adalah perdagangan, pariwisata, transportasi, pendidikan, dan kesehatan (Albulescu, 2020). Usaha Kecil dan Menengah merupakan kelompok entitas yang paling terancam karena tidak memiliki sumber daya untuk bertahan dari krisis. Konsekuensi yang akan terjadi akibat krisis ekonomi adalah meningkatnya peran intervensi negara dan lembaga keuangan internasional. Kebijakan negara berupa penundaan pinjaman dan pembayaran pajak, pengambilalihan sebagian pekerjaan atau biaya jaminan sosial dengan anggaran pusat, mengutamakan keselamatan dan penanggulangan bencana (Selkowski, 2020).

Bisnis digital menggunakan teknologi untuk menciptakan nilai baru dalam model bisnis, pertumbuhan ekonomi digital membuat masyarakat lebih mudah dan lebih mengenal produk layanan digital yang mendorong perusahaan untuk mencari keuntungan baru di ruang digital. Bisnis digital menciptakan keunggulan kompetitif berdasarkan kombinasi luar biasa dari sumber daya digital dan fisik dan membangun keunggulan komparatif. Bisnis digital mengubah cara organisasi dalam menggunakan dan berpikir tentang teknologi, inovasi, pendapatan, dan pertumbuhan pasar. Sumber Daya Utama perlu diidentifikasi agar model bisnis berjalan, yaitu berupa; sumber daya fisik, sumber daya intelektual, sumber daya manusia, dan sumber daya keuangan. Proposisi nilai yang baik dibuat agar perusahaan atau UKM dapat mentransfer nilai intrinsik dan nilai tidak berwujud seperti; membuat produk / layanan dapat diakses, menawarkan inovasi, meningkatkan produk / layanan dengan menambahkan fitur yang relevan, menggunakan merek untuk identitas, mengurangi harga produk / layanan, mengurangi risiko yang terkait dengan produk / layanan, dan meningkatkan desain produk (Cavallari, 2015). Saat ini, UKM perlu mempertimbangkan pengembangan bisnis digital.

Strategi digitalisasi yang tepat diperlukan untuk mencapai tujuan bisnis, mengembangkan produk atau layanan UKM agar lebih kompetitif. Keunggulan kompetitif terkait dengan keanekaragaman budaya, pluralitas dan motivasi sosial. Dalam proses transformasi digital, diperlukan pengujian infrastruktur digital yang benar. Langkah-langkah yang perlu dilakukan dalam transformasi digital di UKM adalah sebagai berikut: 1) Menciptakan pola pikir yang benar dan pemahaman bersama; 2) Menentukan kepemimpinan yang tepat; 3) Meluncurkan pusat bisnis digital unggulan; 4) Merumuskan strategi digital; 5) Menemukan, mengembangkan, dan memperoleh pengetahuan; 6) Menciptakan kemampuan digital baru (Casalino, et al., 2020).

Dengan teknologi yang tepat untuk ketahanan sistem, sebuah bisnis dapat melakukan transformasi digitalnya dan menciptakan ketahanan digital. Ketahanan digital adalah keseimbangan antara memanfaatkan peluang dan mengelola risiko digital yang dihadapi, serta keseimbangan antara sumber daya manusia, proses, dan teknologi yang dibutuhkan. Kolaborasi adalah kunci keberhasilan ketahanan digital, dibutuhkan kolaborasi antara kepemimpinan tim dan risiko, tim keamanan dan teknologi serta kolaborasi dengan pemangku kepentingan bisnis utama lainnya seperti; komunikasi dengan komunitas, hukum, pemasaran, dan lain-lain. Dalam melaksanakan kegiatan 
pengabdian kepada masyarakat UMKM Gang Dolly, kami melaksanakan kegiatan ini sesuai dengan metode atau alur yang sudah dipaparkan pada gambar I, yaitu terdapat 6 (enam) kegiatan dimana kegiatan tersebut adalah dibuat berdasarkan tahapan-tahapan yang berjenjang, yaitu: a). Analisis Kondisi Masyarakat; b). Perencanaan dan Perumusan Platform; c). Sosialisasi dan Edukasi; d). Implementasi; e). Monitoring dan Evaluasi dan f). Kaderisasi

\section{Analisis Kondisi Masyarakat}

Tahapan awal yang dilakukan yaitu analisis kondisi masyarakat kelompok sasaran program pengabdian masyarakat, sekaligus kami juga memetakan kondisi UMKM yang masih aktif bertahan saat pandemik covid-19. Berdasarkan survei pendahuluan, kami menemukan beberapa permasalahan umum yang terjadi pada mitra, yaitu: a). UMKM terkendala pemasaran saat pandemik covid-19, sehingga beberapa diantaranya tidak mampu meneruskan usahanya. Mereka yang tidak mampu meneruskan usaha tersebut mengaku bahwa, pendapatan saat pandemik dan ditetapkannya PSBB di Surabaya adalah menjadi faktor utama. Akan tetapi mereka menunggu saat pandemik ini berakhir, maka mereka akan membuka kembali usahanya; b). Pada umumnya kemampuan untuk menggunakan sosial media sebagai media untuk mensosialisasikan produk masih rendah. Sehingga pemasaran yang menggunakan e-commerse masih dalam tahapan membuka toko dan menjual barang dagangannya, hal inilah yang kami anggap perlu untuk diadakan pelatihan mengenai product knowledge dan branding pada media sosial; c). Pengetahuan dasar mengenai UMKM belum ada, sehingga kami akan merefresh kembali pemahaman mereka mengenai UMKM dan manajerial UMKM sederhana. Sehingga para pelaku UMKM dapat lebih paham dan memiliki inovasi untuk mengembangkan usahanya; d). Terdapat beberapa orang yang ingin memiliki usaha, akan tetapi mereka bingung sebaiknya mau usaha dalam bentuk apa ? ada yang sudah mencoba untuk menjadi reseller produk-produk peralatan rumah tangga tapi belum diseriusi. Hal ini mengindikasikan bahwa, diperlukan suatu pemahaman masyarakat mengenai usaha apa yang cocok dengan kemampuan mereka, dimana tentu saja terdapat kendala modal, terbatasnya faktor produksi, dan kurangnya pemahaman masyarakat dalam pemasaran.

\section{Perencanaan dan Perumusan Platform}

Dalam upaya mengatasi permasalahan tersebut, maka kami akan melakukan perencanaan dan pembuatan platform digital mereka, selain memaksimalkan $e$ commerse yang sudah ada. Untuk gambaran platform digital UMKM Dolly kami sudah membuat aplikasinya yang dapat digunakan pada smartphone (Gambar IV.3). Setelah melakukan pelatihan UMKM Dolly, maka kami akan mengoneksikan aplikasi tersebut sehingga semua orang (khususnya pelaku UMKM di Dolly) dapat melihat produk-produk yang dijual secara detail sekaligus melakukan transaksi pembelian secara online dengan menggunakan aplikasi ini. Sehingga pelaku UMKM harapannya dapat semakin massif dalam memperkenalkan produknya tidak hanya dengan aplikasi e-commerce yang sudah ada, tetapi agar calon konsumen dapat mengetahui tentang produk secara lebih lengkap. Aplikasi yang kami namai dengan UMKM Dolly App tersebut sudah kami daftarkan untuk bisa diunduh melalui Google Play akan tetapi masih membutuhkan proses persetujuan dari pihak Google. Hal ini dapat dilihat pada Gambar 2 Tampilan Platform UMKM Dolly dibawah ini. 

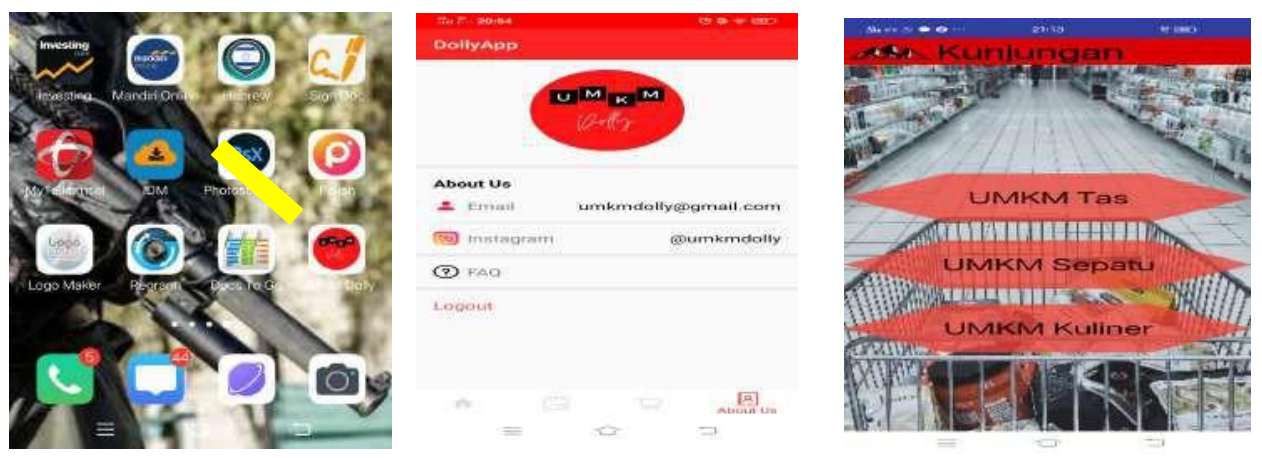

\section{Dasbor}

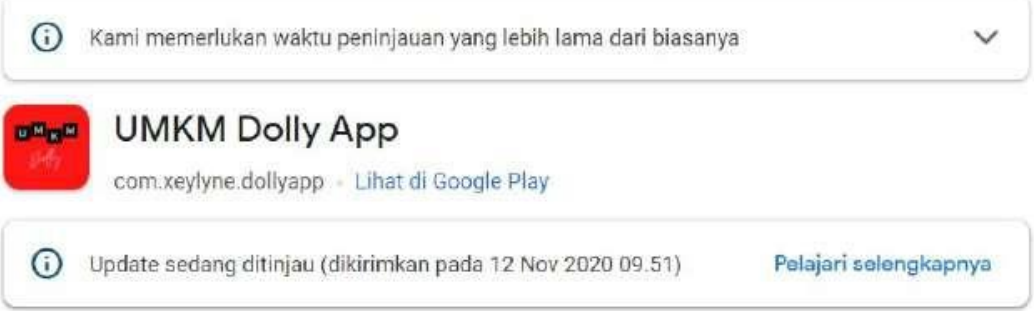

\section{Gambar 2. Tampilan Platform UMKM Dolly}

Platform lain yang kami bangun adalah Instagram, hal ini juga dibutuhkan untuk mempopulerkan produk mereka dalam dunia digital. Akun Instagram dengan nama @ umkmdolly (Gambar 3 Akun Instagram UMKM Dolly) tersebut kedepan akan kami isi dengan serangkaian produk masyarakat binaan, video teaser yang memiliki linkage dengan akun Youtube UMKM Dolly serta kontak nomor handphone maupun email yang kami cantumkan agar masyarakat dapat melakukan transaksi, bekerja sama dengan UMKM, atau mengetahui produk tersebut secara detail.

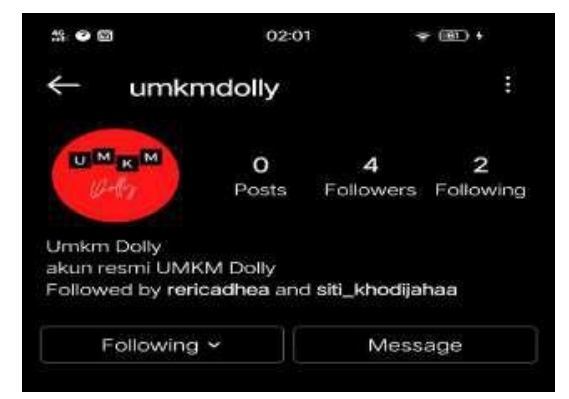

\section{Gambar 3. Akun Instagram UMKM Dolly}

Untuk memberikan pemahaman yang lebih intensif pada pelaku UMKM Dolly, kami juga membuat modul (Gambar 4 Modul Pengabdian Masyarakat UMKM Dolly) yang berkaitan dengan manajerial UMKM, platform pemasaran, dan pembuatan konten video. Harapan kami dengan adanya modul ini, maka dapat diteruskan pada penggiat 
UMKM lain yang ada di eks lokalisasi Dolly sehingga terjadi getok tular dalam ilmu pengetahuan yang berkaitan dengan UMKM.

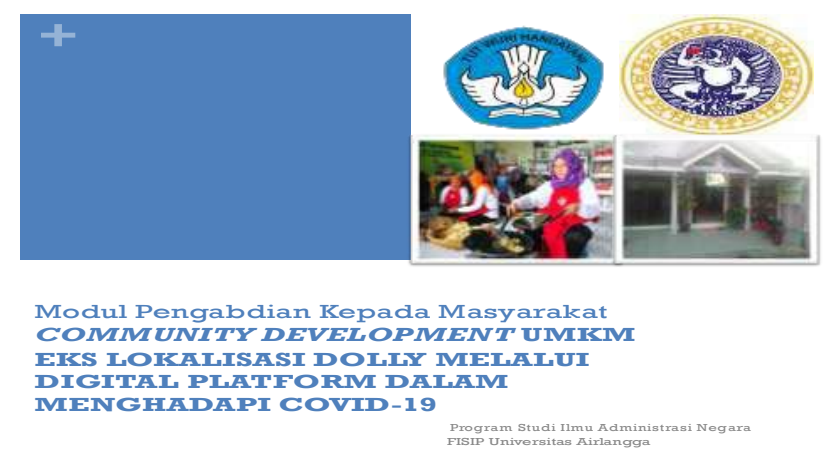

\section{Gambar 4. Modul Pengabdian Masyarakat UMKM Dolly}

\section{Sosialisasi dan Edukasi}

Pelatihan UMKM akan kami lakukan pada pertengahan bulan Oktober, karena kami juga harus menyinkronisasikan waktu yang dimiliki oleh obyek (UMKM) sasaran di RT.5 RW.12 Kelurahan Putat Jaya. Di era pandemik ini pelatihan kami tetap akan melakukan secara offline dengan mematuhi protokol kesehatan covid-19. Pelatihan yang pertama kami berikan dengan tema Manajerial UMKM di Era Global, dimana pelatihan ini kami berikan dengan tujuan untuk memberikan pemahaman kepada masyarakat (baik pelaku usaha, maupun yang sedang merintis usaha) di RT. 5 dan RT. 6, RW.12 Kelurahan Putat Jaya mengenai UMKM, bagaimana mengembangkan pola pikir berwirausaha, dan bagaimana membuka cakrawala pemahaman mereka mengenai kondisi usaha yang memanfaatkan perkembangan teknologi informasi dan komunikasi agar bisa berkembang di era globalisasi (Gambar 5 Pelatihan Manajerial UMKM di Era Globalisasi).

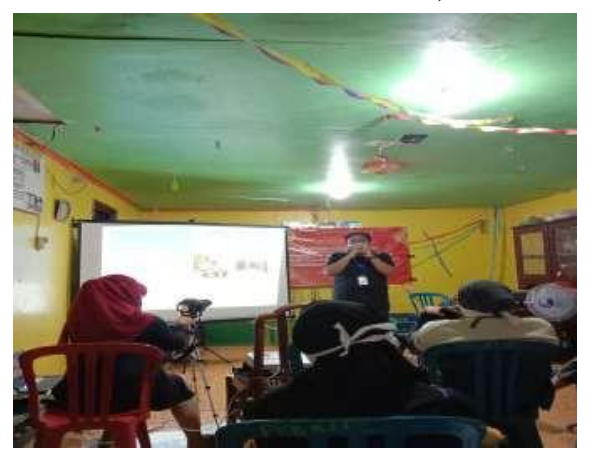

\section{Gambar 5. Pelatihan Manajerial UMKM di Era Globalisasi}

Pelatihan yang kedua kami berikan dengan maksud untuk melakukan sosialisasi mengenai platform digital yang kami kembangkan, yaitu UMKM Dolly. Platform ini dapat diuduh pada laman Google Play, sehingga masing-masing UMKM nantinya yang ada di RT.5 dan RT.6 (tidak menutup kemungkinan semua UMKM di Dolly) akan dapat memanfaatkan platform yang sudah kami buat. Selain itu kami juga menjelaskan bahwa, tim kami akan membuat akun sosial media Instagram UMKM Dolly dan akun Youtube UMKM Dolly (Gambar 6 Sosialisasi Platform Digital UMKM Dolly). 


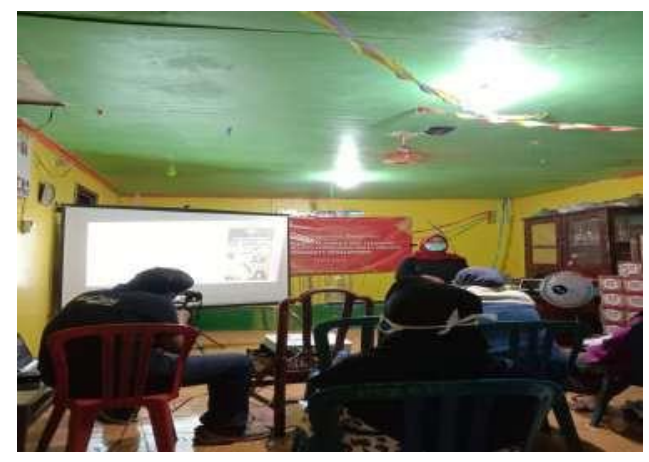

\section{Gambar 6. Sosialisasi Platform Digital UMKM Dolly}

\section{Implementasi Kegiatan}

Dalam uji coba dan implementasi program pengabdian masyarakat, ada sedikit kendala berkaitan dengan pemanfaatan konten yang sudah kami buat. Beberapa produk dari masyarakat masih perlu untuk dilakukan pengemasan supaya lebih menarik, sehingga memang dibutuhkan teknis pengelolaan dalam foto produk. Dari implementasi ini sementara kami membantu memasukkan produk-produk dalam konten yang sudah dibuat, sembari mengajari mitra untuk dapat memasukkan produknya sendiri.

Berkaitan dengan video yang akan ditampilkan pada Youtube untuk menambah value dari produk secara tampilan visual, kendala yang terjadi dilapangan adalah membuat tampilan dan proses editing pada video sehingga dibutuhkan waktu yang lebih panjang untuk membuat suatu video tersebut menarik untuk dilihat. Bersamaan dengan itu kami merencanakan juga selain mengupload produk UMKM, juga melakukan review terhadap produk itu sendiri dengan melibatkan influencer sehingga akan lebih menarik dari segi pemasaran.

\section{Monitoring dan Evaluasi}

Setelah melakukan semua proses kegiatan dalam program pengabdian kepada masyarakat, tim melakukan monitoring dan evaluasi kegiatan untuk mengukur seberapa efektifkan program tersebut kepada masyarakat pelaku UMKM khususnya yang ada di mitra. Dari hasil monitoring dan evaluasi selain kendala yang sudah kami paparkan pada tahapan implementasi, terdapat kendala lain yaitu memang disaat pandemik covid19 yang siklusnya tidak dapat diprediksi secara jelas berdampak kepada usaha yang dimiliki oleh masyarakat dalam UMKM Dolly yang penjualannya jelas menurun. Tetapi saat ini untuk pemanfaatan stan yang disediakan oleh Pemerintah Kota Surabaya sudah berjalan optimal walaupun tetap saja penjualan masih belum dapat dikatakan baik.

\section{Kaderisasi}

Untuk menjamin keberlanjutan dan pemanfaatan platform digital kami melakukan kaderisasi, yang digagas oleh Pak Yulianto sebagai RW 12 Kelurahan Putat Jaya dengan melibatkan beberapa perwakilan dari UMKM yang ada di wilayahnya. Dalam melakukan kaderisasi ini tim kami memberikan modul pelatihan dan melakukan pendampingan dalam mengembangkan UMKM sesuai dengan kondisi eksisting dan kemampuan yang dimiliki oleh masyarakat. 


\section{Publikasi Poster Kegiatan}

Sebagai salah satu luaran berikutnya dari kegiatan kami adalah, tim kami mengirimkan poster program kegiatan pengabdian kepada masyarakat dengan judul Community Development UMKM Eks Lokalisasi Dolly Melalui Digital Platform dalam menghadapi Covid-19, pada acara seminar online oleh World University Associations for Community Development (WUACD) Universitas Airlangga pada tanggal 18 November 2020 dengan judul seminar WUACD On Webinars (WOW) bertema "Higher Education's Community Development Strategy In The Era of Covid-19 Pandemic".

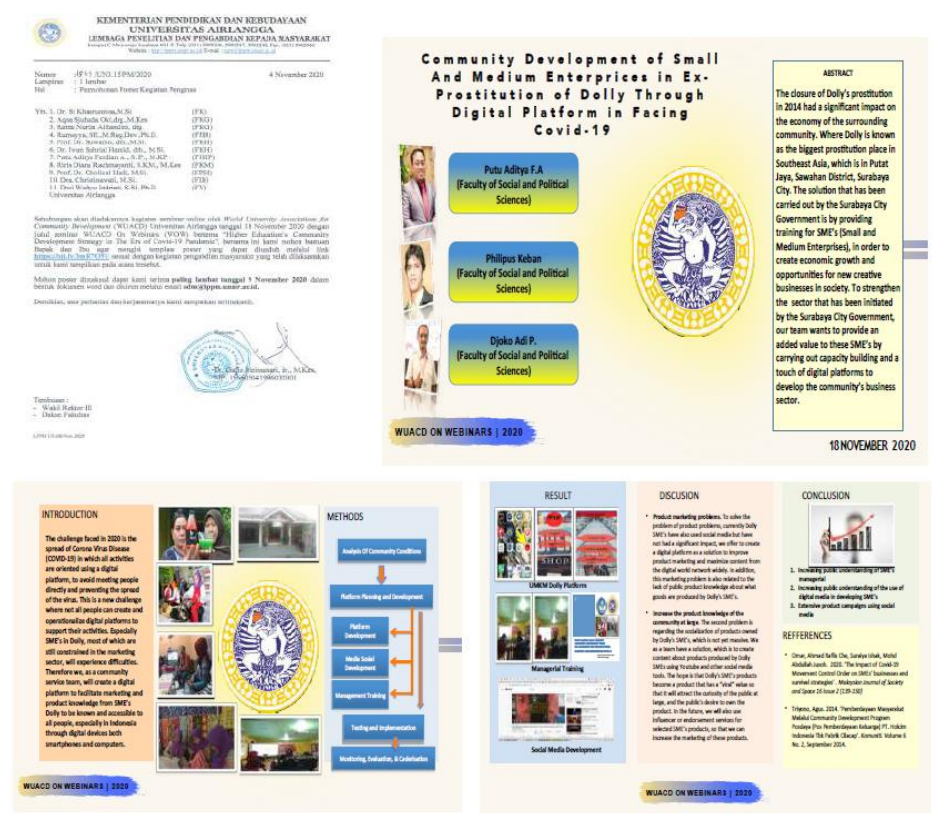

\section{Gambar 7 Permohonan Poster WUACD dan Poster Kegiatan Pengabdian Masyarakat "Community Development on Small and Medium Enterprices in Ex-Prostitution of Dolly Throught Digital Platform in Facing Covid-19"}

\section{PENUTUP}

\section{Simpulan}

Kegiatan pengabdian masyarakat dalam kondisi pandemik covid-19 memang mengalami kendala terutama pada pelaksanaannya yang tentu saja harus mematuhi serangkaian protokol kesehatan yang ketat. Tema yang kami ambil dalam kegiatan ini adalah lebih berorientasi pada pengembangan kegiatan perekonomian yang memanfaatkan platform digital sebagai salah satu metode untuk mengurangi dampak penyebaran covid-19 ketika kegiatan perekonomian dijalankan secara luring. Kendala yang muncul adalah walaupun masyarakat (khususnya pada lokus pengabdian masyarakat yang memiliki bidang usaha atau UMKM kami di Dolly) sudah sangat paham mengenai e-commerce dan ada yang sudah melakukan transaksi tapi hanya menjadi pelanggan, belum pada tataran pengguna atau yang memiliki lapak pada $e$-commerce. Kami juga memandang tidak hanya memanfaatkan $e$ commerce yang sudah ada, tapi lebih kepada membangun suatu platform dan mempopulerkan produk tersebut pada konten digital sehingga produknya bisa lebih meluas. Oleh sebab itu pada tahapan implementasi kami lakukan pertama adalah sosialisasi potensi peluang dari pemasaran dengan menggunakan media digital yang 
sudah ada, sekaligus untuk membangun platform digital baru yang kami namai UMKM Dolly yang sudah bisa diunduh melalui Google Play Store.

\section{Saran}

Sesuai dengan kondisi eksisting di masyarakat secara umum kegiatan pengabdian masyarakat tidak bisa hanya dijalankan secara satu periode saja, hal ini sesuai dengan hasil monitoring dan evaluasi kami memang diperlukan suatu kegiatan pendampingan yang konsisten. Oleh sebab itu kegiatan tersebut memang juga harus didukung oleh segala lini, baik dari perguruan tinggi maupun pemerintah daerah setempat (dalam hal ini Pemerintah Kota Surabaya) yang melibatkan mitra strategis yaitu BUMN/D maupun pihak swasta dalam mengembangkan sektor perekonomian yang ada di masyarakat. Jika kegiatan hanya berjalan satu periode atau satu tahun saja hal ini belum tentu cukup, karena masyarakat mengharap pendampingan ekstra dan tentu hal itu juga membutuhkan daya dukung ekstra baik tenaga tim pendamping kegiatan pengabdian masyarakat serta pendanaan sebagai daya dukung kegiatan.

\section{Daftar Pustaka}

Albulescu, C. (2020). Coronavirus and financial volatility: 40 days of fasting and fear. Published Mar 9. arXiv preprint arXiv: 2003.04005.

Casalino, N and Żuchowski, I and Labrinos, N and Munoz N, Ángel L and Martín-J, José A. (2020). 'Digital Strategies and Organizational Performances of SMEs in the Age of Coronavirus: Balancing Digital Transformation with An Effective Business Resilience'. Law and Economics Yearly Review Journal - LEYR, Queen Mary University, London, UK, Vol. 8, part 2, pp. 347-380, 2020; ISSN 2050-9014.

Cavallari, M., De Marco, M., Rossignoli, C, Casalino, N. (2015). 'Risk, Human Behavior, and Theories in Organizational Studies'. Proceedings of Wuhan International Conference on E-Business. WHICEB 2015. Wuhan, China, AIS, Association for Information Systems, AIS Electronic Library (AISeL), pp.283-297.

Selkowski, Lukasz. (2020). 'Covid-19 Pandemic, Recession, Virtual Revolution Leading to De-globalization?'. Journal of Intercultural Management; Vol.12 No.1 pp 1-11. 